\title{
The English Occupation of Tangier (1661-1683)
}

\section{Author(s): Enid Routh}

Source: Transactions of the Royal Historical Society, New Series, Vol. 19 (1905), pp. 61-78 Published by: Cambridge University Press on behalf of the Royal Historical Society Stable URL: http://www.jstor.org/stable/3678227

Accessed: 26-06-2016 10:49 UTC

Your use of the JSTOR archive indicates your acceptance of the Terms \& Conditions of Use, available at

http://about.jstor.org/terms

JSTOR is a not-for-profit service that helps scholars, researchers, and students discover, use, and build upon a wide range of content in a trusted digital archive. We use information technology and tools to increase productivity and facilitate new forms of scholarship. For more information about JSTOR, please contact support@jstor.org.

Cambridge University Press, Royal Historical Society are collaborating with JSTOR to digitize, preserve and extend access to Transactions of the Royal Historical Society 


\section{THE ENGLISH OCCUPATION OF TANGIER (I66I-I683). ${ }^{1}$}

By MISS ENID ROUTH, F.R.HIST.S.

Read April 13, 1905.

WhEN Charles II. announced his impending marriage with Catharine of Portugal, the inclusion of Tangier in the Princess's dowry was the most popular clause of the marriage treaty.

English hopes ran even higher round the little African port than over the companion gift of Bombay, for Tangier, situated almost on the north-west point of Morocco, lay in the direct trade route from the Levant to Western Europe. The English Consul at Lisbon pointed out ${ }^{2}$ that it might from its position become a magazine for all the Levant, a port which would be used by the Spanish West India fleet homeward bound to Seville or Cadiz, in order to avoid the high duties imposed by the. Crown of Spain in its own portsvaluable asset this in case of war with Holland, Spain, or France.

It was, moreover, easy to see the advantage to English merchantmen in a friendly port open to them in case of need, for piracy was rife in the Mediterranean, and 'Sallee rovers' Corsairs from Algiers, Tripoli, and Tunis, with privateers of all nations, preyed upon such small trading vessels as ventured to pursue their calling without efficient convoy. Numbers of Christian prisoners-many Englishmen among themwere taken every year by Moorish pirates; the tale of their sufferings under the barbarous treatment of their captors was repeated throughout Europe; warfare carried on against

1 References are to State Papers (P. R. O.), Col. Corresp., Tangier, unless otherwise stated. For further titles, see pp. 77, 78.

2 State Papers, Portugal, v. 200, P. R. O. 
these pirates assumed the character of a post-mediæval Crusade, and the acquisition of Tangier was welcomed as a means of putting down the terror of the Mediterranean and of advancing the interests of Christendom.

Queen Luisa of Portugal appears to have been glad enough to be honourably rid of a possession which was too costly to be maintained by her country, now involved more deeply than ever in the struggle to defend its liberty against its Spanish neighbour, and thought it none too high a price to pay for a renewal of the English alliance; the Portuguese inhabitants of Tangier, however, were indignant at the cession to English heretics of a city which was almost the last remnant of their country's once considerable dominions in Africa.

Tangier had been abandoned to Portugal by the Moors in $147 \mathrm{I}$, and passed into Spanish hands, with the rest of the Portuguese possessions in these parts, in 1580 . When, in 1640, Portugal succeeded in throwing off the Spanish yoke, Tangier with Ceuta yet remained in the possession of Spain, but the former city reverted to the Portuguese three years later. Spain, however, at the time of the English occupation still looked on Tangier with jealous eyes, professing to regard it as a rebel city, ${ }^{1}$ and refusing to recognise the justice of England's claim to its possession.

Charles II.'s policy in regard to Tangier, admirable in principle, though it proved disastrous in detail, is embodied in his instructions to Lord Peterborough, ${ }^{2}$ the first Governor of Tangier, as follows :- 'Our main design in putting Ourself to this great charge for making this addition to our Dominions being to gaine our Subjects the Trade of Barbary and to enlarge our Dominions in that Sea ... we are gratiously pleased that no duties or customs or other taxes whatsoever shall be laid by us upon any good imported to or exported from Our city of Tanger, and . . . it shall be and remain a free port.' Lord Peterborough's commission appointed him GovernorGeneral of 'Our city of Tangier and suburbs thereof, and of

1 Col. Corresp., Tangier, iii. 37.

2 State Papers, No. $\mathrm{I}$. 
all other Cities Towns and Villages, Forts Castles and Islands, Lands and Countries which now are or which hereafter shall be delivered or reduced to our obedience.' ${ }^{1}$ It is, then, perhaps only just to give to Charles II. and his advisers the credit for a bold and hopeful scheme of colonial expansion, in place of the useless tenure of French or Dutch cautionary towns; for it is clear that the English Court, ignoring all difficulties, hoped by the possession of Tangier to build up a large and profitable trade with Morocco, to gain the all-important advantage of a secure footing in the Mediterranean, to ensure the safety of English merchant ships in that sea, and to make Tangier a watch-tower against the designs of Spain and the nucleus of an extensive commercial empire on the coast of North Africa. Unfortunately, Charles II.'s Government was unable to realise this ambitious scheme, for its success depended on (I) the command of the sea, which was hard to maintain owing to the unserviceable condition of many of the king's ships, and (2) on the regular despatch of adequate supplies, which financial embarrassment often made impossible. The whole story of the occupation of Tangier, as told in the 'State Papers,' is one of indifference, ignorance, and mismanagement on the part of Ministers at home, of self-interest, peculation, and carelessness on the part of most of the governors of the city, and of an heroic struggle maintained by the garrison, to which was entrusted the almost hopeless task of defending the place against a fanatical and able enemy, while hampered by an insufficiency of men, money, arms, ammunition, and almost everything that is necessary to carry on a successful campaign. The English Consul at Lisbon had, indeed, reported the Moors to be 'a very effeminate people,' ${ }^{2}$ to be easily kept at bay by 2,000 European troops, and Peterborough was accordingly despatched with about 3,000 men, one regiment being raised by himself in his own name, ${ }^{3}$ and the rest sent from

\footnotetext{
1 State Papers, No. I.

2 State Papers, Portugal, v. 200.

- State Papers, Tangier, i., September 13, 1661.
} 
Dunkirk. ${ }^{1}$ The first establishment consisted of four regiments, ${ }^{2}$ which were in 1763 reorganised into two, ${ }^{3}$ one English and one Irish, of 1,000 men each, and later still into one, ${ }^{4}$ the old Tangier Regiment, now the Queen's Royal West Surrey Regiment. The cost of the establishment was estimated at 70,000l. a year, ${ }^{5}$ and by an Order in Council of October 25, $166 \mathrm{I}$, the pay of the garrison was to be carefully provided and paid quarterly. ${ }^{6}$

The English forces reached Tangier Bay on January 29, 1662, and on the next day Lord Peterborough marched into the town at the head of his regiment and received the keys of the gates from the Portuguese Governor.

Lord Sandwich, who had been guarding Tangier until the arrival of the troops, did good service in aiding their disembarkation, and before his departure made a survey of the bay, with a view to finding the best place for the famous mole, in accordance with instructions from home. A fortnight later Lord Sandwich's fleet left the garrison to make the best of its position in the isolated town, flanked by sandhills, with an unexplored country beyond them, which it was directed to make ready for English settlers and merchants. The place was left by the Portuguese inhabitants 'very little better than a ruine of walls,' ${ }^{7}$ as Peterborough reported to the Lords of the Council, and 'full of spoile scarsity and want as to all such materialls and utensills as could have given assistance to English souldiers.' 8 The Portuguese carried away everything they could get on board ship, even to 'the very ffloers, the Windowes and the Dores.' The ruined condition of the town and fortifications turned the Governor's attention to the need of making terms with the Moorish chief whom the English called 'Gayland,' ${ }^{9}$ and whom they soon came to know only too well. This prince, who held precarious sway

1 State Papers, Tangier, i., Instructions to Peterborough : undated.

2 Davis, p. I9.

- Ibid. vi. 12I, and viii. 30 .

3 State Papers, Tangier, ii. 66.

- Ibid. i. 46.

Ibid. i. 90.

- Ibid. ii. 22.

I Ibid. i. 92.

- 'Abd Allah Ghaïlàn. 
over twenty-two neighbouring tribes, is quaintly described as follows in a pamphlet dated $1664^{1}$ :-

' His person looks handsomer than his condition; his look is fat and plain, but his nature close and reserved. $\mathrm{He}$ is plump, yet melancholy ; valiant, yet sly ; boisterous, yet of few words ; careful, and intemperate, a contradiction in nature. He hath two qualities that may do anything-(I) Perfidiousness ; (2) Cruelty. When he swears most solemnly, then you may be sure he lyeth, so treacherous he is, and when fawns most basely, then you must look for mischief, so bloody he is.' The army with which this redoubtable chief appeared before Tangier Peterborough described as 'about 5,000 horse, able, dexterous, sober, valliant, incomparably well armed and cloathed, and horsed.' ${ }^{2}$ The Governor made every effort to obtain a treaty of peace with the Moors, but Ghailàn's terms were impossible and the negotiations fell through. (He demanded fifty barrels of powder, the use of English ships whenever he wanted them, and the prohibition of trade between Tangier and Tetuan, with which place he was at war. $)^{3}$ After this constant skirmishes took place between the garrison and the Moors, and urgent requests were sent home for arms and ammunition, 'the Gunns being the greatest part dismounted, and the rest with carriages unfit for service on any occasion.' 4

Before the end of the year Charles II. instituted the Tangier Committee, ${ }^{5}$ which numbered among its members the Duke of York, Prince Rupert, Lord Sandwich, Mr. (afterwards Sir Hugh) Cholmley, and Samuel Pepys, who was appointed Treasurer in 1665 , and to whom most of our information regarding the proceedings of the Committee is due.

One of the earliest acts of the Commissioners was to place a contract for building the mole ${ }^{6}$ with Lord Rutherford (afterwards Lord Teviot and Governor of Tangier), Sir John Lawson, and Mr. Cholmley. The object was to improve the harbour, naturally a poor one, by affording protection against

1 A Description of Tangier, Brit. Mus.

${ }^{3}$ Ibid. i. 1 10. 'Ibid. i. $92 . \quad 5$ Ibid. i. 147.

N.S.-VOL. XIX.

2 State Papers, i. 109.

6 Ibid. ii. 16-21. 
the violent storms of the Atlantic and the strong Levant winds. The price agreed upon was $\mathrm{I} 3 \mathrm{~s}$. (afterwards $\mathrm{I} 7 \mathrm{~s}$.) per cubic yard; but in 1669 , Sir H. Cholmley being the only surviving contractor, the contract was cancelled and Cholmley appointed surveyor-general of the work.

The mole was built on the north of the bay, where a ledge of rocks formed a natural protection. It was the greatest engineering work as yet undertaken by Englishmen, and Sir Hugh gives an interesting account of it. ${ }^{1}$

It was, he says, the first work of the kind ever attempted in deep water and with a flowing tide. He experienced much difficulty from (I) the uncertainty of the weather; (2) the softness of the stone obtained from local quarries; (3) the silting up of sand in the bay ; and (4) 'the very bad and dilatory payment by tallies' anticipated from twentyfour to thirty months. 'Instead of money,' he says, 'he never got anything but orders upon the Exchequer, which ... were scarce passable upon any terms.' His original account, preserved in the Audit Office, shows that he received from the Treasury between March 1763 and June 1776 the sum of $265,108 l$. I 4 s. $8 \frac{1}{2} d$. Sir Hugh had much trouble to persuade 'masons, miners, and other artists and workmen' 2 to go to Tangier from England, and the mole was built almost entirely by soldiers of the garrison; in 1665 Lord Belasyse wrote that 400 soldiers were daily employed on the mole and fortifications, and he asked for two more companies, 'to make up $y^{e}$ establishment to 2,000 foot, as in my Lord Teviot's time. ... We labour and toyle like horses to promote these great workes,' he added, 'and our dewty is soe hard as 'tis impossible to perform it under a less number.' ${ }^{3}$

In 1665 a battery was built on the Mole, and proved a valuable defence to seaward. ${ }^{4}$ In 1668 the length of the mole was 380 yards, its mean width being 36 yards; but the storms of 1670 and 1674, when Sir Hugh was in England, caused serious damage both to his work and reputation,

1 An Account of Tangier.

2 State Papers, iv. 40.

${ }^{3}$ Ibid. iv. 76.

4 Ibid. iv. I05. 
though 'he knew,' he said, 'how to cure the evil, if the perplexities of an Exchequer account could give him leave to go to Tangier.' He offered to repair the breaches made by the storms, carry the mole 100 yards farther into the sea (making a harbour of 4 fathoms at low water), and complete the whole in six years. He was much disappointed when the Commissioners accepted the counter-proposals of Mr. Shere, a young engineer, who was strongly in favour of imitating the new mole at Genoa, and making the foundations of 'chest-work,' i.e. great wooden chests, filled with stones and cement, weighing from 500 to 2,000 tons. Sir Hugh thought that no solid and contiguous structure could possibly resist the force of the Atlantic; for, he says, at Whitby, where neither loose rocks nor solid masonry could withstand the heavy seas, he 'happened to observe that a small tree (set up as a mark for shipping) stood the same seas that laid level the body of a work so massy, . . . and concluded that this came because the sea had a free passage about the tree.' His own idea was to protect the mole by rows of piles 'shod with iron and well steeled at the points,' and pillars of masonry set corner-wise to the incoming tide. Mr. Shere seems to have had little more success than his predecessor, for after 1675 only 42 more yards were completed, ${ }^{1}$ and after 1679 the work ceased, every available man being needea to defend Tangier against the Moors.

Lord Teviot's Government, from I663-64, was perhaps the most hopeful period of the occupation; though he, like other Governors, was open to the charge of wasting the king's money to his own profit, ${ }^{2}$ and he was thoughtless enough to forget that the soldiers under his command would need provisions during their voyage to Tangier. ${ }^{3}$

Teviot, however, was a keen soldier, and his troops shared his enthusiasm. He at once set to work on extensive fortifications, and tried to gain Ghailàn's consent to the continuation

1 Total length about 478 yds. Shere's Report, Dartmouth MSS., vol. i. p. 102.

2 Pepys's Diary, September 30, 1663, and May 19, 1664.

3 State Papers, ii. 173. 
of the English lines $;^{1}$ but the Moor sent word that the Mohammedan law would not permit him to allow Christians to erect fortifications in Africa. ${ }^{2}$ Fighting began, and the Moors were repulsed after a hot attack. A letter from Tangier at this time tells of Teviot's energy and popularity ${ }^{3}$ : 'His $\mathrm{Ex}^{\mathrm{ce}}$ has his tent close by the new ffort,' the letter runs, 'where he eats and lodges constantly, having not laid in a bed this month. All sorts of persons receive great satisfactions in his government, and are much encouraged to serve their Prince under so prudent a conduct.' The Moors, the writer adds, regard Teviot with superstitious fear, saying that ' he is a man of success and cannot be beaten.'

Teviot himself wrote hopefully, saying, 'it is wonderful the progress we have made in fortifying our retranchments by the indefatigable pains and labour of our sogers and the extraordinary diligence of our officers, all stryving to surpass one another for his $\mathrm{Ma}^{\text {ties }}$ service ... if his Ex : Gayland ... doe not attaque us with all his forces to-morrow or Monday I dare answer to his Majestie to put a paire of spectacles on Gayland's nose $y^{t}$ will trouble him so as to oblige him at last to a peace. . . . Nay, which is more, that for attaquein I dare almost promise good success, for I never saw officers and sogers more eager and ready to fight. . . . I hope my next sall efford better news.' 4

But all these hopes were shattered by the fatal disaster of May 4, 1664, when Teviot, encouraged by the success of his reconnaissances, and thinking the country clear, ordered the horse to forage to the south-east, while he himself, wrote Colonel Bridges in his official report, ${ }^{5}$ resolved 'to goe into the wood with some foot to cutt wood,' and 'went over the valley to the west hill ... and tooke with him 7 battalions ... the best and choycest of our men;... . but so it was, before they came up to the middle partey of the hill in the wood, several ambushes of foote discovered themselves, which ... . our men drove to
1 State Papers, iii. 20.
4 Ibid. iii. 34.
2 Ibid. iii. 34 .
3 Ibid. iii. 32.
5 Ibid. iii. 53 . 
a retreate, but presently on all handes they rose up and appeared in such great numbers that they immediately had surrounded our men; at the same time the horse started upp round about in the valley and on the hills to the S.E. not less than 2,000, and came pouring downe not only upon our horse, but tooke the advantage in a moment to fall betweene the wood where our foot were, and the hill, that although it was evident our men fought as resolutely, and gave as good fyer as men could doe, they being thus surrounded with their army of horse and foote, our worthy Gen ${ }^{\text {rll }}$, the officers and gentlemen with him, and all the whole party of the soldiers were cutt off, not 30 of them as I can find that ever came off.' Nearly 500 men were lost with Teviot in this engagement. The Moors themselves paid so dearly for their success that they did not venture to renew the attack for some time, and Colonel Alsop wrote a month later ${ }^{1}$ that not an inch of ground nor a single man had been lost since the Earl's death. The condition of Tangier after this reverse was, however, extremely serious, ${ }^{2}$ and the dangers threatening the weakened garrison were increased by the existence of negotiations between Spain and the Moors, which were notified by Consul Wescombe as early as $1663 .{ }^{3}$ That the Spaniards, and particularly the Duke of Medina Celi, were now supplying the Moors with arms and powder may be gathered from the correspondence of Wescombe with the Governor of Tangier, which was kept up by means of a boat plying between Tangier and Tarifa every week. ${ }^{4}$ This enabled the Tangier despatches to be sent home overland, via Madrid, with greater safety and regularity than could be ensured by sea.

The Dutch war of 1665 rendered the English tenure of Tangier still more precarious; eighteen Dutch men-of-war attempted to blockade the town, ${ }^{5}$ and though the guns on the mole prevented an attack, these eighteen ships, Wescombe says, ${ }^{6}$ captured twenty-five English vessels in or about the

1 Fanshaw MSS., p. 158.

3 Ibid. ii. 134 .

2 State Papers, iii. 71, 73, 110.

5 State Papers, iv. 105.

4 Fanshaw, p. 195, and State Papers, iii. 216.

6 Fanshaw, p. 220. 
Straits in the course of a year, several being laden with provisions for Tangier.

After 1665 things went from bad to worse; letters of this and succeeding years contain bitter complaints of neglect in England, where more pressing affairs absorbed the attention and resources of the Government. Letters from a Governor of Tangier to the Secretary of State often lay unanswered for months together ; supplies were slow, insufficient, of poor quality, ${ }^{1}$ and badly convoyed $;^{2}$ in spite of reiterated demands for a few ships to patrol the coast, ${ }^{3}$ not one was available to prevent the capture of Sallee by Ghailàn, ${ }^{4}$ or to check the raids of Moorish pirates, who took many English captives. Great difficulty was experienced in obtaining lime for the fortifications, since its importation from Spain was prohibited $;^{5}$ there was scarcity of building materials of every kind, ${ }^{6}$ though the heavy rains of winter had disastrous effect on the mud walls both of fortifications and houses, and made repairs imperative. ${ }^{7}$ Constant petitions were sent home for the pay of the garrison, seldom less than nine months in arrears, while in 1772 more than two years' pay was owing, so that even when the Moors brought in fresh provisions the soldiers either could not buy them, or were forced to give arms and ammunition in exchange $;^{8}$ and a diet of salt meat and bread made of musty flour drove them, says Sir Hugh Cholmley, when they did get ' a flood of money, to spend it all in a week,' 9 for the most part on bad brandy, and this, coupled with the insanitary state of the town, spread disease among the garrison $;{ }^{10}$ many even died for want of food, and the hospital, Sir Hugh writes, 'is soe badd, men fly it as the grave.' Water was sometimes scarce, for many wells became dried up and lost ; the Portuguese Governor had given Peterborough a valuable plan of all conduit-heads and heads of watercourses, but it was never seen after he left Tangier, and he always said coolly that 'he had mislaid it.' "11

1 State Papers, iv. Io2.

2 Ibid. iv. 166 .

3 Ibid. iv. 65.

7 Ibid. iv. Io.

4 Ibid. iii. 256.

8 Davis, p. 105.

5 Ibid. iii. I60. 6 Ibid. iv. I5.

State Papers, iv. 43 .

10 Ibid. iv. 167 .

"Smith, Life of Pepys, p. 444. 
For some time after the disaster of 1664 expeditions beyond the English lines were considered 'useless and dangerous,' ${ }^{1}$ and the vitality of the colony was impaired by the impossibility of expanding its boundaries. Ghailàn was engaged in fighting Moorish rivals, and the English officers finding life in Tangier unbearably monotonous, ${ }^{2}$ frequently overstayed their leave. Their only communication with the outside world was by means of ships, and England was three weeks' voyage away; the 'newsbooks' sent by Consul Wescombe from Cadiz were very welcome to men who saw (as Teviot said) 'nothing but Moors and the four elements.' 3

Lord Belasyse, however, wrote enthusiastically of Tangier when he arrived in the spring of 1765 , and found 'All $y^{e}$ orrange-trees tipped with flowers,' which he 'left in England so with snow and ice.' ${ }^{4}$

' His Ma ${ }^{\text {ty }}$ ' he thought, 'would have a greater esteame off it than any other off his dominions, weare he heare to see $y^{\circ}$ prospects off $y^{\mathrm{e}}$ Streights uppon Spain, the shipps that pass, the frutefull mountagnes off Affrique, the fragrent perfumes off flowers, rare frutes and sallads, excellent ayre, meates and wines, which this place most seamingly affords, or shall doe.'

In 1766 Lord Belasyse was fortunately able to conclude a peace with the Moors, ${ }^{5}$ which left him free to repair the old out-works and to sow corn within certain limits, and the English after this even helped Ghailàn, until his death, in his unsuccessful struggle against Er Rasheed II., ' The Great Tafiletta.' This prince was looked upon with suspicion by the garrison, owing to his correspondence with the French, ${ }^{6}$ who were said to 'intend to make themselves famous for seeking out a footing' in Morocco. ${ }^{7}$

The Tangier Committee was much exercised by the costliness of maintaining the garrison, and in 1668 the establishment was reduced. Pepys wrote (1667): 'It is plain we do overspend our revenue; it is of no more profit to the king than it was the first day ... no more people of condition willing to live

\footnotetext{
1 State Papers, iv. 72.

Ibid. iv. 71 .

2 Ibid. iii. 2 I4.

s Ibid. vi. 27.

3 Ibid. iii. 42.

6 Ibid. vi. 51.
}

7 A Description of Tangier, Brit. Mus. 
there, nor anything like a place likely to turn his Majesty to account; it hath been hitherto, and for aught I can see likely only to be, used as a job to do a kindness to some lord, or he that can get to be governor.'

In 1668 the Committee obtained a charter establishing a civil government, or corporation for the better governing of Tangier, consisting of a mayor ( $\mathrm{Mr}$. Bland), six aldermen, and twelve common council ; but disputes soon arose between the civil and military authorities, and Major Fairborne wrote, ' was not the souldiery part very strictly governed, and the officers a well-tempered sort of gentlemen, Mr. Bland's great pride, with his foolishness, would soon breed a great distraction among us.' ${ }^{\prime}$ Lord Middleton, Governor from 1670 till his death in 1675, when Lord Inchiquin succeeded him, reconciled the conflicting parties to some extent, and effected considerable improvements in the details of administration. The enemy with whom the garrison had to deal after 1672 was no less a personage than the Emperor Mulai Ismail, who was as notorious for his unparalleled cruelty and the great number of his Christian slaves as he was famous for his consolidation of the crumbling Empire of Morocco.

'He excells all mankind in barbarous and bloody actions,' wrote an Englishman in 1682, 'massacre and murder being his Royal game and divertisement, which, that it may not cloy his Majesty in one kind, he invents every day a new pastime of cruelty.' 2

Ismail deputed the Alcaild Omar of Alcazar to conduct the great siege of Tangier in the spring of 1680 , when the garrison lost the outer forts and had to fight hard to keep the town itself. ${ }^{3}$ In May a four months' truce was arranged, and in October the garrison at last quitted the defensive and, after more hard fighting, ${ }^{4}$ in which Admiral Herbert and his sailors gave valuable help, ${ }^{5}$ won a complete victory over the Moors, pursuing them for a mile into the open country and regaining all the ground they had lost; though Fairborne,

1 State Papers, x. II3. 2 Last Account from Fez. ${ }^{3}$ State Papers, xxix. 30.

- Ibid. xxix. 202.

s Tangier's Rescue, 168I. 
who had been the moving spirit of the defence, was mortally wounded and died at the moment of victory.

After 1680 relations with Ismail grew more friendly; fortunately for Tangier, for, in spite of this great success, the garrison became very demoralised under Colonel Kirke ${ }^{1}$ (Governor in I68I) and hardly capable of resisting attack. Kirke reported that 'the great guns are the worst that ever were in any garrison,' ${ }^{2}$ the gunners 'are the worst that ever man saw-there is not ten knows the gun from the carriage ;' and as for the 'firemaster,' another letter says he 'is certainly a most ignorant person as to the knowledge of any ingredient save brandy.'

In February 168I Kirke went on an embassy to Ismaïl at $\mathrm{Fez}$, where we are told ' the king returned more favourable answers than could be expected from a prince so haughty' and promised four years' peace. The Embassy was entertained at Mequinez, which they said was 'extremely delightful, the walks being adorned with rows of orange trees, that grew through a pleasant and glittering pavement of painted tiles; the aqueducts and canals of water springing in the middle represent a pleasant and most beautiful scene and charming prospect.' $^{3}$ Sir James Leslie concluded peace with Ismail in May, and in December a Moorish ambassador was sent to London. The last days of the occupation were, however, now approaching; the hopes with which it was undertaken were still unfulfilled; Charles's 'faithful Commons' feared that Tangier was becoming 'a nursery for Papists' and a stepping-stone to promotion for 'desperate Popish officers '; they answered his recommendation of the place to their care by a refusal to give the matter any consideration until they were 'effectually secured from the imminent and apparent dangers arising from the power of Popish persons and councils' (November 29, I680).

Want of money decided the English Government in 1683 to send Lord Dartmouth to Tangier, ${ }^{4}$ with orders to make a

\footnotetext{
1 Smith, Life of Pepys, p. 403.

3 Last Account from Fez." 
minute survey of the place, fortifications and mole, and estimates of the cost of maintaining them, and with secret instructions to make his reports justify the determinationalready taken, though not yet made public-of abandoning Tangier to the Moors.

Lord Dartmouth's surveyors worked out their estimates of expenditure necessary for the safety of Tangier during the next twelve years at something over $£ 2,000,000$, and a list of reasons for destroying the mole was drawn up by Mr. Shere, ${ }^{1}$ though he said privately that 'he could answer them all.' He estimated that the work of demolition would take seven or eight months.

Pepys, who accompanied Lord Dartmouth, was engaged in making a valuation of houses, and comments on the ' habits of disorder' of the inhabitants. His final impressions of Tangier seem to have been very unfavourable. 'But Lord!' he wrote, 'how could anybody think a place fit to be kept at this charge that, overlooked by so many hills, can never be secured against an enemy?' It was 'an ordinary place,' he thought, and, 'above all that was remarkable there,' was 'fine Mrs. Kirke, the Governor's lady:' On October I3, 1683, Lord Dartmouth publicly read his commission from the King authorising him to withdraw 'all his subjects and forces ' from the place, 'rendering it desolate.'

During the winter the fortifications of Tangier were reduced to a heap of ruins. The mole was demolished with great difficulty, but, according to the official report, was 'so entirely ruinated and destroyed, and the harbour so filled with stones and rubbish,' that neither the mole nor bay was ' in any capacity to afford protection to the ships or vessels of any pirates, robbers, or any enemies of the Christian faith, or any others.' The desertion of Tangier seems to have given satisfaction on the whole, though there were some dissentient voices.

Pepys, in the midst of his complacent reflections on the loss of the place, received a letter imploring him to use all

1 Dartmouth MSS. i. 102. 
his influence to save it.' 'Must a place qualified with so many advantageous and unequalled benefits,' wrote his correspondent, 'be parted with on the score of its being chargeable, and we the only people that ever thought so ? Where is the honour and reputation of the nation? That alone, a man should think, were sufficient argument for its preservation. The parting with 'it in any manner will render us very inconsiderable and necessitous to all the world, for what will they think of us, esteem or dread us, if we cannot maintain a place so much our convenience to preserve ? ... The parting with the place may draw a war on us. . . . And must nothing in future be minded, but, all in a heat, a present charge be removed, which were better maintained than altered?'

The Moors triumphantly watched the process of evacuation, which they attributed, quotes Budgett Meakin from a Moorish writer, ${ }^{2}$ to sheer fright, believing till this day that they alone drove the English from Morocco.

By March 1684 Lord Dartmouth's work was complete, and the last of the English sailed away from their ill-fated possession, giving up all hope of making Tangier the startingpoint of a North African empire, and leaving it to sink to the level of a second-rate Moorish port, which, in spite of recent diplomatic efforts, still merits the reputation of being, as Amicis described it, 'the point where the last wave of European civilisation is lost in the great dead sea of African barbarism.'

The present paper is an attempt to indicate the results of a very partial examination of the several sources of information in this country alone relating to the oft-told story of the English occupation of Tangier in the reign of

1 Charles Russell to Pepys. Smith, Life, Journals, and Correspondence of Pepys, pp. $3^{86}$ and $3^{87}$.

2 Moorish Empire, p. I54. 
Charles II. Amongst the many points of interest connected with the subject which have not been touched upon in this general sketch, the following should be specially noticed :-

I. Diplomatic relations and negotiations with Portugal concerning the cession of Tangier.

IA. Financial arrangements and cost of the occupation.

2. The commercial relations of England with Spain, Portugal, and Holland, as far as they bear on the condition of Tangier.

3. The conditions of trade and of the shipping engaged in it in the Mediterranean, and especially on the African coast.

4. The proceedings of the Tangier Committee.

5. Methods of provisioning the garrison.

6. Military regulations and English and Moorish strategy at Tangier.

7. Progress of fortifications and enclosure of ground round Tangier.

8. The question of the usefulness of the mole.

9. Civil government and population of the town.

I0. English relations with the Moors, particularly with Mulaì Ismaîl.

II. Treatment of Jews and other foreigners at Tangier.

12. The Sallee Rovers and the treatment of Christian slaves in Morocco.

12A. The fitting out of English privateers at Tangier.

The sources which have been referred to may be briefly described as follows :-

I. PUblic ReCord OfFice.-(i) State Papers, (a) Colonial Correspondence, Tangier, consisting of a large number of letters dated from Tangier; reports and letters from the successive Governors of the place, usually addressed to the principal Secretary of State ; instructions to the Governors ; orders on the Treasury for payment of moneys for the garrison; reports of the Tangier Commissioners, and many law papers, dealing chiefly with suits for debt heard in the court of justice at Tangier, the whole giving a good picture of the state of the place during the English occupation. 
(b) State Papers for Portugal and Spain. A series of letters from the English Consuls in those countries referring to Tangier, and dealing with English commercial relations with the Spaniards and Portuguese.

(c) Domestic State Papers.

(ii) Exchequer Records.-The Audit Office and Pipe Office Declared Accounts give information about the finances of Tangier, accounts of the military Governors, paymasters, treasurers, and contractors, and Sir Hugh Cholmley's account for the mole.

(iii) Navy Board and War Office Papers, the latter being of small importance.

II. In the Pepysian Library at Cambridge there are notices to be found in Captain Bolland's Mediterranean Papers (a report on the Mediterranean ports and currents by an officer of the Mole, 1676), Naval Miscellanies, Shere's Straits of Gibraltar, $A$ Consul's Letters from Algiers, and Narbrough's Journals.

III. Some of Pepys's Tangier Papers are in the Rawlinson Collection at the Bodleian, where also there are other references.

IV. The MSS. at the British Museum contain miscellaneous references to Tangier; a few letters from Tangier are in the Harley MSS. and a few in the Lauderdale Papers; the Sloane Collection contains minute-books of courtsmartial at Tangier, a court book of civil and criminal cases, and papers relating to the governments of Peterborough, Belasyse, and Middleton. There are in the British Museum several contemporary maps, plans, and views of Tangier.

V. The reports of the Historical MSS. Commission on the Fanshaw and Dartmouth MSS. give many interesting particulars, the former of the earlier years of the occupation, the latter of its closing chapter, the demolition of Tangier under Lord Dartmouth.

VI. Of printed works giving valuable information, it is only necessary to mention Pepys's Diary and Tangier Journal; Sir H. Cholmley's interesting account ${ }^{1}$ of his construction of the mole (privately printed, a copy being in the British 
Museum); a number of contemporary pamphlets and printed letters, also in the British Museum; military histories, especially Colonel John Davis's ' History of the 2nd Queen's Regiment,' which is based on the Tangier papers in the P. R. O., and contains reproductions of plans in the Royal Library at Windsor ; Mr. Frewen Lord's chapter on Tangier in 'Lost Possessions of England'; Mr. Julian Corbett's 'England in the Mediterranean' ; and, for the Moorish side, Mr. Budgett Meakin's 'Moorish Empire and Land of the Moors,' and M. Chenier's 'Recherches historiques sur les Maures.'

Sir Lambert Playfair's' Bibliography of Morocco' gives a list of all works on the subject published before 1892 .

1 1. An Account of Tangier, and, 2, $A$ Short Account of the Mole at Tangier. 